Check for updates

Cite this: RSC Adv., 2019, 9, 18320

Received 25th January 2019

Accepted 31st May 2019

DOI: $10.1039 / c 9 r a 00652 d$

rsc.li/rsc-advances

\section{Preparation and photocatalytic performance of tungstovanadophosphoric heteropoly acid salts}

\author{
Dandan Ji, (D) *abc Rong Xue, ${ }^{a}$ Maojuan Zhou, ${ }^{a}$ Ying Zhu, ${ }^{d}$ Fengshan Zhang*b \\ and Lihua Zang*a
}

Tungstovanadophosphoric heteropoly acid $\mathrm{H}_{5} \mathrm{PW}_{10} \mathrm{~V}_{2} \mathrm{O}_{40} \cdot 5.76 \mathrm{H}_{2} \mathrm{O}(\mathrm{HPWV})$ has been synthesized via stepwise acidification and gradual addition of elements. Some metals like $\mathrm{Fe}, \mathrm{Al}$ and $\mathrm{Cu}$ were introduced into the heteropoly acid (HPA) in the molar ratio of $10: 6,10: 6$ and $10: 4$ respectively. The prepared catalysts were characterized by UV, FTIR, TG/DTA and XRD. The results indicated that HPWV and its metal salts all contain Keggin units, which are the primary structures of the heteropoly acids. The homogeneous photocatalytic degradation of phenol by heteropoly acid salts was studied in detail under artificial UV irradiation and addition of hydrogen peroxide $\left(\mathrm{H}_{2} \mathrm{O}_{2}\right)$, and the effects of initial phenol and $\mathrm{H}_{2} \mathrm{O}_{2}$ concentrations on the rate of photocatalytic phenol degradation were examined. The results suggested that the heteropoly acid salts showed good catalytic activities for phenol degradation via the . $\mathrm{OH}$ radical mechanism. Under irradiation with a $10 \mathrm{~W} \mathrm{Hg}$ lamp, 96\% phenol was degraded within less than $60 \mathrm{~min}$ in the solution containing $50 \mathrm{mg} \mathrm{L}{ }^{-1}$ phenol $+2 \mu \mathrm{mol} \mathrm{L}{ }^{-1} \mathrm{Fe}_{5}\left(\mathrm{PW}_{10} \mathrm{~V}_{2} \mathrm{O}_{40}\right)_{3}+4 \mu \mathrm{mol} \mathrm{L}{ }^{-1}$ $\mathrm{H}_{2} \mathrm{O}_{2}$, with the performance of the catalysts in order FePWV > AlPWV > CuPWV > HPWV. This work demonstrated that the photo-Fenton reaction catalyzed by the heteropoly acid salts was a promising advanced oxidation tool for the treatment of phenol-containing wastewater.

\section{Introduction}

Advanced oxidation processes (AOPs), defined as a set of tools that utilize radicals (for example $\cdot \mathrm{OH}, \mathrm{SO}^{\cdot 4-}$ and so on) ${ }^{1}$ for oxidation, have received increasing attention in the degradation of bio-refractory organic compounds in wastewater treatment processes. AOPs can be classified into several categories, depending on the different reagent systems used for the generation of radicals, such as ultraviolet or visible radiation, catalytic ozonation, photocatalytic ozonation, photocatalytic oxidation and Fenton-like processes. Among different AOPs, Fenton and photo-Fenton oxidation processes are environmentally friendly because they do not involve the use of hazardous chemical reagents. ${ }^{2}$ In addition, these methods are easy to handle and can be operated with uncomplicated design reactors. In the last past few decades, the homogeneous-Fenton reaction has been considered to be one of the most efficient methods for the treatment of polluted water containing

${ }^{a}$ College of Environmental Science and Engineering, Qilu University of Technology (Shandong Academy of Science), Jinan, Shandong, China 250353. E-mail: zlh@qlu. edu.cn; jdd@qlu.edu.cn; Tel: +86053189631680

${ }^{b}$ Huatai Group, Guangrao, Shandong, China 257335. E-mail: htjszx@163.com; Tel: +8605467798857

'Jiangsu Key Laboratory of Anaerobic Biotechnology, Jiangnan University, Wuxi, Jiangsu, China 214122

${ }^{d}$ Advanced Material Institute, Qilu University of Technology (Shandong Academy of Science), Jinan, Shandong, China 250014 recalcitrant chemicals. ${ }^{3-6}$ The Fenton technique is based on an electron transfer between hydrogen peroxide and a homogeneous metal in solution, generally iron(II) $\left(\mathrm{Fe}^{2+}\right)$, causing the formation of hydroxyl radicals. ${ }^{7}$ The reactions are described as follows:

$$
\mathrm{Fe}^{2+}+\mathrm{H}_{2} \mathrm{O}_{2} \rightarrow \mathrm{Fe}^{3+}+\mathrm{OH}^{-}+\cdot \mathrm{OH} \text { (Fenton reaction), }
$$

followed by the regeneration of $\mathrm{Fe}^{3+}$ ions to active $\mathrm{Fe}^{2+}$ with $\mathrm{H}_{2} \mathrm{O}_{2}$ :

$$
\mathrm{Fe}^{3+}+\mathrm{H}_{2} \mathrm{O}_{2} \rightarrow \mathrm{Fe}^{2+}+\mathrm{HO}_{2}^{\cdot}+\mathrm{H}^{+}\left(\mathrm{Fe}^{2+} \text { regeneration }\right)
$$

The photo-Fenton method combined of UV irradiation and Fenton process, has been developed in order to improve the oxidation efficiency of the most recalcitrant organic compounds. ${ }^{8}$ In this process, the oxidation rate increases, leading to a higher degree of mineralization due to the enhanced production of $\cdot \mathrm{OH}$ radicals. Hydroxyl radicals are generated from the photo-decomposition of hydrogen peroxide and the decomposition of its iron-catalyst: ${ }^{9}$

$$
\mathrm{H}_{2} \mathrm{O}_{2}+\mathrm{UV} \rightarrow \cdot \mathrm{OH}+\cdot \mathrm{OH} \text { (photolysis of } \mathrm{H}_{2} \mathrm{O}_{2} \text { ) }
$$

$\mathrm{Fe}^{2+}+\mathrm{H}_{2} \mathrm{O}_{2} \rightarrow \mathrm{Fe}^{3+}+\mathrm{OH}^{-}+\cdot \mathrm{OH}$ (photo-Fenton reaction)(4)

In the past few years, there has been significant research efforts in the search for alternative technologies for the photo- 
Fenton reagent for degradation of various organic pollutants and pathogens. ${ }^{10,11}$ Depending on the activity of the catalyst used, photo-Fenton catalytic degradation methods have been demonstrated to be one of the most innovative, green and efficient alternative treatments of organic wastewater. Numerous studies have reported on photo-Fenton reagents for dealing with different organic pollutants in batch experiments. ${ }^{12-16}$ Among these, recently, there has been growing interest in the use of nanoparticles as photocatalytic agents ${ }^{17-20}$

Heteropoly acids (HPAs) and their derivatives represent an increasingly important class of eco-catalysts for many organic reactions. ${ }^{21}$ HPAs are formed by inorganic metal-oxygen cluster anions and compounds with strong Brønsted acid characteristics and unique redox properties. The strong Brønsted acidity is caused by two main reasons: such as dispersion of the negative charge over lots of atoms of the polyanion and the fact that the negative charge is less distributed over its outer surface due to the double-bond character of the $\mathrm{M}-\mathrm{O}_{\mathrm{d}}$ bond, polarizing the negative charge of $\mathrm{O}_{\mathrm{d}}$ to $\mathrm{M} \cdot{ }^{22}$ For HPA-catalyzed reactions, the conventional mechanism of Brønsted acid catalysis was widely accepted, including two catalysis types of surface and bulk. Generally, the catalytic activity of HPA may be higher, 3-100 times, than conventional organic and inorganic acids. In addition, HPAs salts are good water-tolerant hydrophobic solid catalysts as well as having biphasic reaction systems containing an aqueous phase. Taking advantage of these properties, the HPAs have been mainly applied as catalysts for acid catalysis and catalytic synthesis. ${ }^{23,24}$ More importantly, the use of heteropoly acids as catalysts is at the forefront of fundamental and applied catalysis. ${ }^{25}$ As a special class of multifunctional materials, heteropoly acids and their polyoxometalates have been payed considerable attention due to their important applications in a variety of fields such as nonlinear optics, magnetism, and medicine, and in particular as a catalyst material. ${ }^{26}$ Furthermore, their potential applications in fuel cells, electrochemical capacitors, and other electrochemical devices. ${ }^{27}$

In this paper, phosphotungstovanadic heteropoly acids with the formula $\mathrm{H}_{5} \mathrm{PW}_{10} \mathrm{~V}_{2} \mathrm{O}_{40} \cdot 5.76 \mathrm{H}_{2} \mathrm{O}$ were synthesized using the hydrothermal method. $\mathrm{Fe}_{5}\left(\mathrm{PW}_{10} \mathrm{~V}_{2} \mathrm{O}_{40}\right)_{3}(\mathrm{FePWV}), \mathrm{Al}_{5}\left(\mathrm{PW}_{10} \mathrm{~V}_{2^{-}}\right.$ $\left.\mathrm{O}_{40}\right)_{3}(\mathrm{AlPWV})$, and $\mathrm{Cu}_{5}\left(\mathrm{PW}_{10} \mathrm{~V}_{2} \mathrm{O}_{40}\right)_{2}(\mathrm{CuPWV})$ were obtained by doping $\mathrm{H}_{5} \mathrm{PW}_{10} \mathrm{~V}_{2} \mathrm{O}_{40} \cdot 5.76 \mathrm{H}_{2} \mathrm{O}$ with $\mathrm{Fe}, \mathrm{Al}$ and $\mathrm{Cu}$. Then, their performance and mechanism in the photo-Fenton reaction were investigated.

\section{Materials and methods}

\subsection{Synthesis of $\mathrm{H}_{5} \mathrm{PW}_{10} \mathrm{~V}_{2} \mathrm{O}_{40} \cdot 5.76 \mathrm{H}_{2} \mathrm{O}$}

$\mathrm{H}_{5} \mathrm{PW}_{10} \mathrm{~V}_{2} \mathrm{O}_{40} \cdot 5.76 \mathrm{H}_{2} \mathrm{O}$ (HPWV) was synthesized by using a modification of the method described in previous study. ${ }^{28} \mathrm{~A}$ $20 \mathrm{~mL}$ aqueous solution of sodium phosphate $\left(3.80 \mathrm{~g}, \mathrm{Na}_{3^{-}}\right.$ $\mathrm{PO}_{4} \cdot 12 \mathrm{H}_{2} \mathrm{O}$ ) was added dropwise to an $80 \mathrm{~mL}$ aqueous solution of sodium tungstate $\left(32.9 \mathrm{~g}, \mathrm{Na}_{2} \mathrm{WO}_{4} \cdot 2 \mathrm{H}_{2} \mathrm{O}\right)$. The $\mathrm{pH}$ value of the mixture was adjusted to 2.5. Ammonium molybdate $(2.34 \mathrm{~g}$, $\mathrm{NH}_{4} \mathrm{VO}_{3}$ ) was added to the mixture, and the $\mathrm{pH}$ was adjusted to 2.5 again. Then, the mixture was incessancy heated at $140{ }^{\circ} \mathrm{C}$ for $8 \mathrm{~h}$. After cooling, the solution was extracted with ether $(150 \mathrm{~mL})$ in a sulphuric acid medium. The red-orange powder
$\mathrm{H}_{5} \mathrm{PW}_{10} \mathrm{~V}_{2} \mathrm{O}_{40} \cdot 5.76 \mathrm{H}_{2} \mathrm{O}$ was obtained by vacuum drying to remove diethyl ether. The structure formation process of $\mathrm{H}_{5}$ $\mathrm{PW}_{10} \mathrm{~V}_{2} \mathrm{O}_{40} \cdot 5.76 \mathrm{H}_{2} \mathrm{O}$ can be observed by $\mathrm{X}$-ray diffraction methods in the water/dimethyl sulfoxide mixture $(1: 1$ by volume, $20 \mathrm{~mL}$, at room temperature).

\subsection{Preparation of $\mathrm{Fe}_{5}\left(\mathrm{PW}_{10} \mathrm{~V}_{2} \mathrm{O}_{40}\right)_{3}, \mathrm{Al}_{5}\left(\mathrm{PW}_{10} \mathrm{~V}_{2} \mathrm{O}_{40}\right)_{3}$, $\mathrm{Cu}_{5}\left(\mathrm{PW}_{10} \mathrm{~V}_{2} \mathrm{O}_{40}\right)_{2}$}

$\mathrm{H}_{5} \mathrm{PW}_{10} \mathrm{~V}_{2} \mathrm{O}_{40} \cdot 5.76 \mathrm{H}_{2} \mathrm{O}(1.6320 \mathrm{~g})$ was dissolved in a flask with $20 \mathrm{~mL}$ of deionized water. $\mathrm{Fe}\left(\mathrm{NO}_{3}\right)_{3} \cdot 9 \mathrm{H}_{2} \mathrm{O}(0.4040 \mathrm{~g}), \mathrm{Al}\left(\mathrm{NO}_{3}\right)_{3}{ }^{-}$ $\cdot 9 \mathrm{H}_{2} \mathrm{O}(0.3751 \mathrm{~g})$, and $\mathrm{Cu}\left(\mathrm{NO}_{3}\right)_{2} \cdot 3 \mathrm{H}_{2} \mathrm{O}(0.3768 \mathrm{~g})$ were dissolved in $10 \mathrm{~mL}$ of deionized water and dropped into a flask at $80{ }^{\circ} \mathrm{C}^{29}$ The solution was observed for changes in colors during the dissolution. When $\mathrm{Fe}\left(\mathrm{NO}_{3}\right)_{3} \cdot 9 \mathrm{H}_{2} \mathrm{O}$ were added, the solution turned yellow, when $\mathrm{Cu}\left(\mathrm{NO}_{3}\right)_{2} \cdot 3 \mathrm{H}_{2} \mathrm{O}$ were added, the solution turned dark green, and when $\mathrm{Al}\left(\mathrm{NO}_{3}\right)_{3} \cdot 9 \mathrm{H}_{2} \mathrm{O}$ were added, there was no obvious color change. The resulting suspension was dried through evaporation at $80{ }^{\circ} \mathrm{C}$ to dryness to obtain the precursors of the $\mathrm{Fe}_{5}\left(\mathrm{PW}_{10} \mathrm{~V}_{2} \mathrm{O}_{40}\right)_{3}(\mathrm{FePWV}), \mathrm{Al}_{5}\left(\mathrm{PW}_{10} \mathrm{~V}_{2} \mathrm{O}_{40}\right)_{3}(-$ AlPWV) and $\mathrm{Cu}_{5}\left(\mathrm{PW}_{10} \mathrm{~V}_{2} \mathrm{O}_{40}\right)_{2}(\mathrm{CuPWV})$ catalysts.

\subsection{Degradation experiments and characterization}

An immersed UV lamp (10 W $254 \mathrm{~nm}$ ) was used in the experiment. The intensity of light irradiation was $202 \mu \mathrm{W} \mathrm{cm}{ }^{-2}$, which was measured with a radiometer (Vilber-Lourmat) at $254 \mathrm{~nm}$. The reaction temperature kept $25 \pm 1{ }^{\circ} \mathrm{C}$. The effects of initial phenol concentration, reaction time and dosage of $\mathrm{H}_{2} \mathrm{O}_{2}$ on the removal of TOC and phenol degradation were examined. Phenol and its degradation products were determined using a $15 \mathrm{C}$ HPLC with an SPD-15C UV-vis detector and an Inertsil/ WondaSil C-18 reverse-phase chromatographic column (Shimadzu, Japan). The mobile phase was a mixture of water and acetonitrile $(60: 40, \mathrm{v} / \mathrm{v})$ at $1 \mathrm{~mL} \mathrm{~min}^{-1}$. The detection wavelength was $210 \mathrm{~nm}$. TOC was measured using a Shimadzu TOC analyzer. FT-IR spectrum was recorded using an IR Prestige-21 FT/IR spectrometer (Shimadzu, Japan) over the 400$4000 \mathrm{~cm}^{-1}$ wavenumber range. The UV spectrum was determined using a TU-1810 PC UV-vis spectrophotometer. The X-ray powder diffraction (XRD) was obtained using a Bruker D8 ADVANCE X-ray diffractometer at $40 \mathrm{kV}$ and $40 \mathrm{~mA}$ in the range of $2 \theta=3-40^{\circ}$ at a rate of $0.02^{\circ} \mathrm{s}^{-1}$. The thermal stability of the sample was performed using thermogravimetry (TG) methods from room temperature to $800{ }^{\circ} \mathrm{C}$, which was conducted by a TGA Q50 in a nitrogen stream, with a scanning rate of $10{ }^{\circ} \mathrm{C} \mathrm{min}^{-1}$. All reagents were analysis grade.

\section{Results and discussion}

The absorption band of the $\mathrm{H}_{5} \mathrm{PW}_{10} \mathrm{~V}_{2} \mathrm{O}_{40} \cdot 5.76 \mathrm{H}_{2} \mathrm{O}$ UV spectrum indicates the charge-transfer between a coordinated metal atom and oxygen. The absorption band at 200-260 $\mathrm{nm}$ comes from the electron transfer of the bridge-oxygen to metal atoms in the Keggin unit. ${ }^{30}$ The absorption peaks of $\mathrm{H}_{5} \mathrm{PW}_{10} \mathrm{~V}_{2} \mathrm{O}_{40^{-}}$ $\cdot 5.76 \mathrm{H}_{2} \mathrm{O}$ appear at $202 \mathrm{~nm}$ and $252 \mathrm{~nm}\left(\mathrm{O}_{\mathrm{b}} / \mathrm{O}_{\mathrm{c}} \rightarrow \mathrm{W}\right)$ (Fig. 1). This result presents that compounds contain Keggin units. 


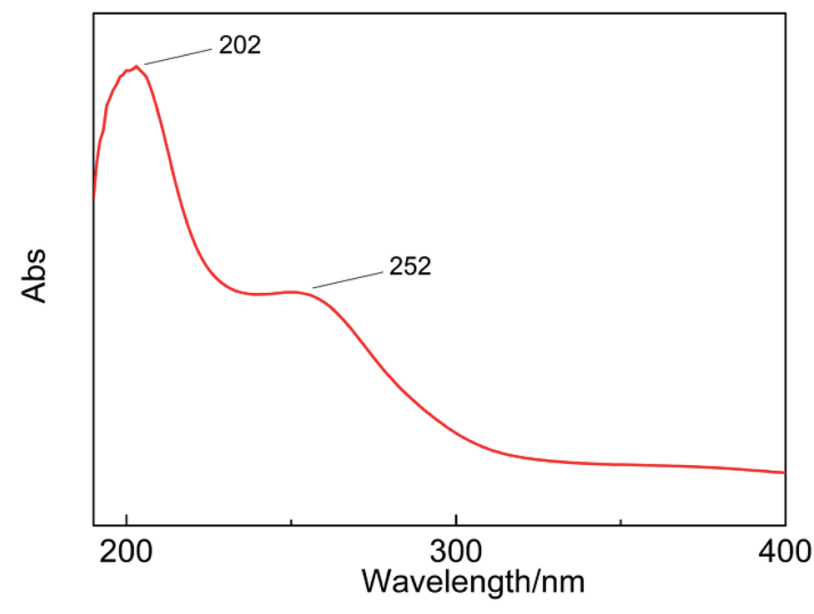

Fig. 1 UV spectrum of pristine $\mathrm{H}_{5} \mathrm{PW}_{10} \mathrm{~V}_{2} \mathrm{O}_{40} \cdot 5.76 \mathrm{H}_{2} \mathrm{O}$ in water.

The characteristic $790-1080 \mathrm{~cm}^{-1}$ bands of heteropolyanion with the Keggin structure are observed. Moreover, the vibrational frequencies are in the sequence $v_{\mathrm{as}}\left(\mathbf{M}-\mathrm{O}_{\mathrm{c}}-\mathbf{M}\right)<v_{\mathrm{as}}\left(\mathbf{M}-\mathrm{O}_{\mathrm{b}}-\right.$ $\mathrm{M})<v_{\mathrm{as}}\left(\mathrm{M}-\mathrm{O}_{\mathrm{d}}\right)<v_{\mathrm{as}}\left(\mathrm{P}-\mathrm{O}_{\mathrm{a}}\right)(\mathrm{M}=\mathrm{W}, \mathrm{V})$. The IR spectra of HPA and its salts are shown in Fig. 2. It is clear that HPAs show frequency shifts relative to the spectrum of original HPA. Stand of the vibration modes of all $\mathrm{M}-\mathrm{O}$ bonds are strongly influenced by the interactions between the solvents and neighboring anions. The stretching modes show that $\mathrm{O}_{\mathrm{b}}$ or $\mathrm{O}_{\mathrm{c}}$ atoms are

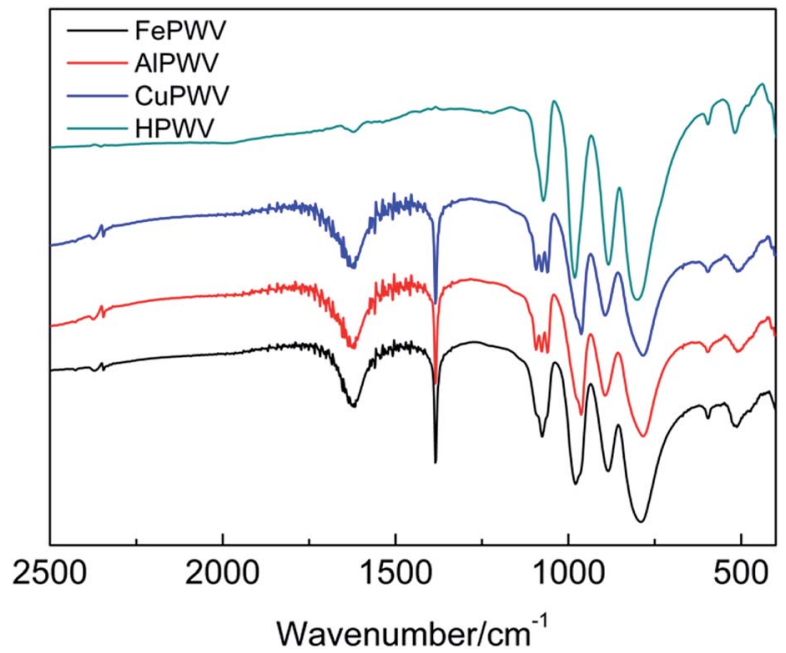

Fig. 2 IR spectra of catalysts. different owing to the mixed bending-stretching character, which can be deduced from geometrical considerations. Because $\mathbf{M}-\mathrm{O}_{\mathrm{b}}-\mathbf{M}$ and $\mathbf{M}-\mathrm{O}_{\mathrm{c}}-\mathbf{M}$ vibrations are not pure and cannot be cast off from bending character, the antagonistic with the opposite effect is present. The abatement in the electrostatic anion-anion interactions results in a reduce in the stretching frequencies, but causes an increase in the bending vibrations. As a result, the frequency shifts of $\mathrm{M}-\mathrm{O}_{\mathrm{b}}-\mathrm{M}$ and $\mathrm{M}-\mathrm{O}_{\mathrm{c}}-\mathrm{M}$ may present different transformation. The wavenumber of the $\mathbf{M}-$ $\mathrm{O}_{\mathrm{b}}-\mathrm{M}$ asymmetrical stretching vibrations increases from $882 \mathrm{~cm}^{-1}\left(\mathrm{H}_{5} \mathrm{PW}_{10} \mathrm{~V}_{2} \mathrm{O}_{40}\right)$ to $886 \mathrm{~cm}^{-1}\left(\mathrm{Fe}_{5}\left(\mathrm{PW}_{10} \mathrm{~V}_{2} \mathrm{O}_{40}\right)_{3}\right)$, $895 \mathrm{~cm}^{-1}\left(\mathrm{Al}_{5}\left(\mathrm{PW}_{10} \mathrm{~V}_{2} \mathrm{O}_{40}\right)_{3}\right)$, and $895 \mathrm{~cm}^{-1}\left(\mathrm{Cu}_{5}\left(\mathrm{PW}_{10} \mathrm{~V}_{2} \mathrm{O}_{40}\right)_{2}\right)$. The frequency of the $\mathrm{M}-\mathrm{O}_{\mathrm{c}}-\mathrm{M}$ asymmetrical stretching vibrations decreases from $802 \mathrm{~cm}^{-1}\left(\mathrm{H}_{5} \mathrm{PW}_{10} \mathrm{~V}_{2} \mathrm{O}_{40}\right)$ to $790 \mathrm{~cm}^{-1}$ $\left(\mathrm{Fe}_{5}\left(\mathrm{PW}_{10} \mathrm{~V}_{2} \mathrm{O}_{40}\right)_{3}\right), 786 \mathrm{~cm}^{-1}\left(\mathrm{Al}_{5}\left(\mathrm{PW}_{10} \mathrm{~V}_{2} \mathrm{O}_{40}\right)_{3}\right)$, and $786 \mathrm{~cm}^{-1}$ $\left(\mathrm{Cu}_{5}\left(\mathrm{PW}_{10} \mathrm{~V}_{2} \mathrm{O}_{40}\right)_{2}\right)$.

The complete correlative assignments of vibrational peaks are described in Table 1. Although there are four characteristics peaks of the Keggin structure ranging from $700 \mathrm{~cm}^{-1}$ to $1100 \mathrm{~cm}^{-1}$, Keggin units still exist in both compounds. The bands in the 1620 to $1650 \mathrm{~cm}^{-1}$ range are attributed to the bands corresponding to the $\mathrm{H}-\mathrm{O}-\mathrm{H}$ bending vibrations. The results of FTIR indicated that there are no significant changes in Keggin structure comparing HPA with their salts. Therefore it is reasonable to assume that the metals of $\mathrm{Fe}, \mathrm{Cu}$ and $\mathrm{Al}$ is not incorporated in the primary Keggin structure. In all probability, they occupy positions as counter-cations. This was also proved by the characteristic peaks appeared at $1384 \mathrm{~cm}^{-1}$ in HPA salts, which corresponded to symmetrical bend of the $\mathrm{O}-\mathrm{Fe}, \mathrm{Cu}$ or Al. ${ }^{31}$

Generally, HPAs consist of protons, water, and HPAs anions. TG and DTA curves of the HPA synthesized in the study are shown in Fig. 3. The total percent weight loss of the powder product is $5.65 \mathrm{wt} \%$, indicating that 8.70 water molecules are lost during thermogravimetric analysis. The peak in the temperature range of $100-200{ }^{\circ} \mathrm{C}$ corresponding to the loss of hydration water, which are hydrogen-bonded to the acidic protons to form the $\left[\mathrm{H}_{2} \mathrm{O} \cdots \mathrm{H}^{+} \cdots \mathrm{OH}_{2}\right]$ ions and were calculated to be $5.76 \mathrm{H}_{2} \mathrm{O}$ molecules per formula unit. The peak in the range 220 to $350{ }^{\circ} \mathrm{C}$ due to the loss of $1.41 \mathrm{H}_{2} \mathrm{O}$ molecules per unit corresponding to protonated water. As for the peak at the temperature $380{ }^{\circ} \mathrm{C}$, it was accounted for the loss of 0.5 molecules of structural water per formula unit. ${ }^{32-34}$ So, the accurate molecular formula of the product is $\mathrm{H}_{5} \mathrm{PW}_{10} \mathrm{~V}_{2} \mathrm{O}_{40} \cdot 5.76 \mathrm{H}_{2} \mathrm{O}$.

The X-ray powder diffraction (XRD) patterns of HPA and its metal salts is presented in Fig. 4. The XRD patterns of the hybrid

Table 1 Complete correlative assignments of vibrational peaks of catalysts

\begin{tabular}{|c|c|c|c|c|c|}
\hline \multirow[b]{2}{*}{$\mathrm{H}_{5} \mathrm{PW}_{10} \mathrm{~V}_{2} \mathrm{O}_{40} \cdot 5.76 \mathrm{H}_{2} \mathrm{O}$} & \multicolumn{5}{|c|}{ Wavenumber $\left(\mathrm{cm}^{-1}\right)$} \\
\hline & 1620 & 1071 & 983 & 882 & 802 \\
\hline $\mathrm{Fe}_{5}\left(\mathrm{PW}_{10} \mathrm{~V}_{2} \mathrm{O}_{40}\right)_{3}$ & 1620 & 1075 & 979 & 886 & 790 \\
\hline $\mathrm{Cu}_{5}\left(\mathrm{PW}_{10} \mathrm{~V}_{2} \mathrm{O}_{40}\right)_{2}$ & 1620 & $1095-1063$ & 959 & 895 & 786 \\
\hline Vibrations & $\begin{array}{l}\mathrm{H}-\mathrm{O}-\mathrm{H} \\
\text { Bending }^{35}\end{array}$ & $\begin{array}{l}\mathrm{P}-\mathrm{O}_{\mathrm{a}} \\
\text { Stretching }\end{array}$ & $\begin{array}{l}\mathrm{M}-\mathrm{O}_{\mathrm{d}} \\
\text { Stretching }\end{array}$ & $\begin{array}{l}\mathrm{M}-\mathrm{O}_{\mathrm{b}}-\mathrm{M} \\
\text { Stretching }\end{array}$ & $\begin{array}{l}\mathrm{M}-\mathrm{O}_{\mathrm{c}}-\mathrm{M} \\
\text { Bending }^{36}\end{array}$ \\
\hline
\end{tabular}




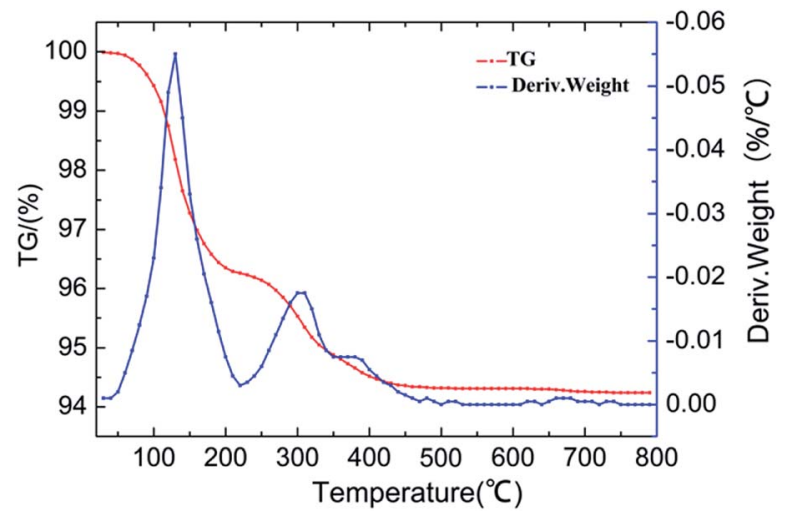

Fig. $3 \mathrm{TG}$ and deriv. weight curves of $\mathrm{H}_{5} \mathrm{PW}_{10} \mathrm{~V}_{2} \mathrm{O}_{40} \cdot 5.76 \mathrm{H}_{2} \mathrm{O}$.

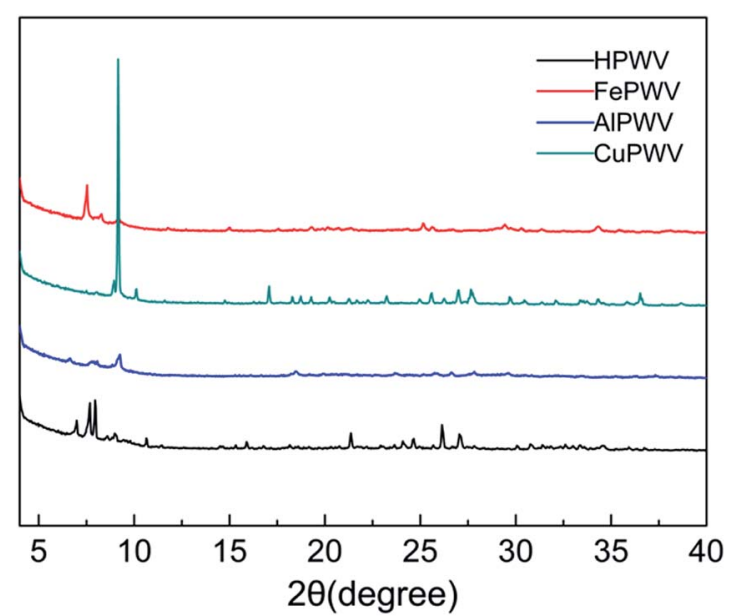

Fig. 4 XRD powder patterns of pristine HPA and its metal salts.

materials are in marked contrast with that of pristine HPA where the most intense peak is present at approximately $7.60^{\circ}$. Despite the introduction of the metal, the characteristic diffraction peaks of $\mathrm{H}_{5} \mathrm{PW}_{10} \mathrm{~V}_{2} \mathrm{O}_{40} \cdot 5.76 \mathrm{H}_{2} \mathrm{O}$ are still conscious of in curves $b$ and $c$ in the range of $2 \theta=6-10^{\circ}$. The sharp diffraction bands at approximately $5-11^{\circ}$ are the properties of the Keggin unit, which indicate the existence of Keggin anions in the metal salts, agreeing with the infrared spectra data. ${ }^{37}$ No peaks corresponding to crystalline phases are visible at $14-40^{\circ}$ of XRD powder patterns for $\mathrm{Fe}_{5}\left(\mathrm{PW}_{10} \mathrm{~V}_{2} \mathrm{O}_{40}\right)_{3}, \mathrm{Al}_{5}\left(\mathrm{PW}_{10} \mathrm{~V}_{2} \mathrm{O}_{40}\right)_{3}$, $\mathrm{Cu}_{5}\left(\mathrm{PW}_{10} \mathrm{~V}_{2} \mathrm{O}_{40}\right)_{2}$. These features indicate that these HPA metal salts consist of a mostly amorphous structure.

The effects of different metal heteropoly acid salts on the degradation of phenol were shown in Fig. 5a, showing performance in order of FePWV $>$ AlPWV $>$ CuPWV $>$ HPWV, similar to the results of Oturan ${ }^{38}$ The enhancement of catalytic activity of metal heteropoly acid salts comparing with HPWV was mainly attributed to the synergetic effect between Brønsted acid catalysis and Fenton process. Among these metal heteropoly acid salts, moly site shows the best catalytic effect. This may be explained by the fact that Fe shows superior catalytic activity in comparison to the other transition metals. ${ }^{39}$

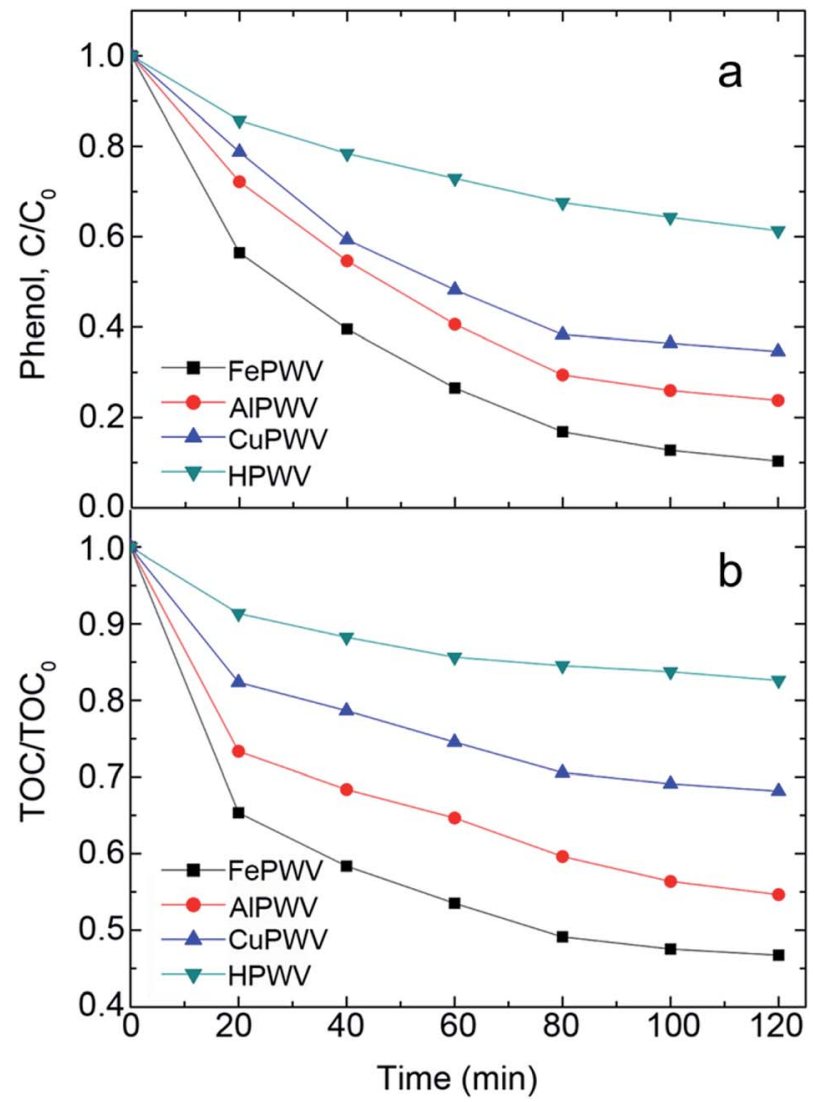

Fig. 5 Effect of different catalyst on (a) phenol degradation and (b) TOC removal. Reaction condition: $1 \mu \mathrm{mol} \mathrm{L}{ }^{-1}$ catalyst $+50 \mathrm{mg} \mathrm{L}^{-1}$ phenol $+2 \mu \mathrm{mol} \mathrm{L}-1 \mathrm{H}_{2} \mathrm{O}_{2}+10 \mathrm{~W}$ UV lamp.

In the entire reaction, there was no additional acid added to significantly reduce the cost because the $\mathrm{pH}$ was approximately 3 due to the acidity of the heteropoly acid salts. The TOC curves in Fig. $5 \mathrm{~b}$ are basically consistent with the results presented in Fig. 5 a of the TOC removal of up to $54 \%$ after 120 min, showing that this method cannot completely mineralize phenol under experimental conditions. Nevertheless, the method can be used as a pretreatment for a subsequent biological treatment.

The phenol degradation curves under different conditions are shown in Fig. 6. Phenol concentration declined slightly under UV irradiation for $60 \mathrm{~min}$, suggesting that a small amount of phenol was degraded. Following the addition of the $\mathrm{Fe}_{5}\left(\mathrm{PW}_{10} \mathrm{~V}_{2} \mathrm{O}_{40}\right)_{3}$ catalyst to the solution, the rate of the decrease of the curve increased significantly, resulting in phenol degradation of approximately $59 \%$ for $60 \mathrm{~min}$. This is similar to the curve that is obtained when $\mathrm{H}_{2} \mathrm{O}_{2}$ was added to the solution that is related to the generation of hydroxyl radicals. ${ }^{40,41}$ However, because $\mathrm{H}_{2} \mathrm{O}$ can be hydrolyzed to $\mathrm{HO}^{*}$ under UV irradiation via catalysis by $\mathrm{Fe}_{5}\left(\mathrm{PW}_{10} \mathrm{~V}_{2} \mathrm{O}_{40}\right)_{3}$, the phenol degradation curve declined significantly to $96 \%$ when the $\mathrm{Fe}_{5}\left(\mathrm{PW}_{10} \mathrm{~V}_{2} \mathrm{O}_{40}\right)_{3}$ catalyst and $\mathrm{H}_{2} \mathrm{O}_{2}$ were added simultaneously for $30 \mathrm{~min}$, indicating that $\mathrm{H}_{2} \mathrm{O}_{2}$ can be rapidly decomposed to $\mathrm{HO}^{\circ}$ due to both the UV irradiation and the effect of $\mathrm{Fe}_{5}\left(\mathrm{PW}_{10} \mathrm{~V}_{2} \mathrm{O}_{40}\right)_{3}$. For catalyst absorption in the 200-260 $\mathrm{nm}$ range, the results could be explained by the following mechanism: 


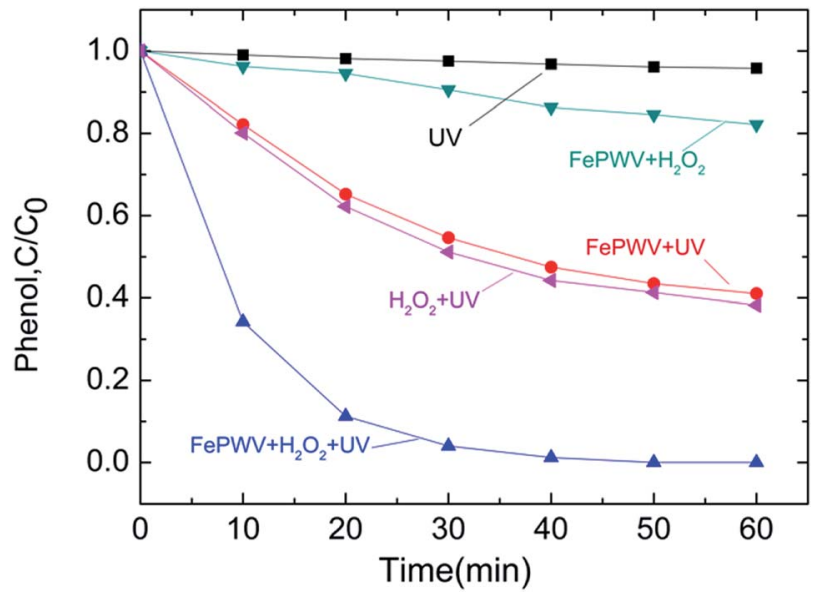

Fig. 6 Phenol removal efficiencies under different reaction conditions. (a) $50 \mathrm{mg} \mathrm{L}^{-1}$ phenol $+10 \mathrm{~W}$ UV lamp. (b) $50 \mathrm{mg} \mathrm{L}^{-1}$ phenol +2 $\mu \mathrm{mol} \mathrm{L}-1 \mathrm{Fe}_{5}\left(\mathrm{PW}_{10} \mathrm{~V}_{2} \mathrm{O}_{40}\right)_{3}+10 \mathrm{~W}$ UV lamp. (c) $50 \mathrm{mg} \mathrm{L}^{-1}$ phenol +2 $\mu \mathrm{mol} \mathrm{L}{ }^{-1} \mathrm{Fe}_{5}\left(\mathrm{PW}_{10} \mathrm{~V}_{2} \mathrm{O}_{40}\right)_{3}+4 \mu \mathrm{mol} \mathrm{L}{ }^{-1} \mathrm{H}_{2} \mathrm{O}_{2}+10 \mathrm{~W}$ UV lamp. (d) $50 \mathrm{mg} \mathrm{L}^{-1}$ phenol $+2 \mu \mathrm{mol} \mathrm{L}{ }^{-1} \mathrm{Fe}_{5}\left(\mathrm{PW}_{10} \mathrm{~V}_{2} \mathrm{O}_{40}\right)_{3}+4 \mu \mathrm{mol} \mathrm{L}{ }^{-1} \mathrm{H}_{2} \mathrm{O}_{2}+$ dark. (e) $50 \mathrm{mg} \mathrm{L}^{-1}$ phenol $+4 \mu \mathrm{mol} \mathrm{L} \mathrm{L}^{-1} \mathrm{H}_{2} \mathrm{O}_{2}+10 \mathrm{~W}$ UV lamp.

$$
\begin{aligned}
\operatorname{MPWV}\left(\mathrm{H}_{2} \mathrm{O}\right)+\mathrm{H}_{2} \mathrm{O}_{2} & \rightleftharpoons \operatorname{MPWV}\left(\mathrm{H}_{2} \mathrm{O}_{2}\right)+\mathrm{H}_{2} \mathrm{O} \\
\operatorname{MPWV}\left(\mathrm{H}_{2} \mathrm{O}\right)+\mathrm{UV} & \rightarrow \operatorname{MPWV}(\mathrm{OH})^{-}+\mathrm{H}^{+} \\
\operatorname{MPWV}(\mathrm{OH})^{-}+\mathrm{H}_{2} \mathrm{O} & \rightarrow \operatorname{MPWV}\left(\mathrm{H}_{2} \mathrm{O}\right)^{-}+\mathrm{HO}^{\cdot} \\
\operatorname{MPWV}\left(\mathrm{H}_{2} \mathrm{O}_{2}\right)+\mathrm{UV} & \rightarrow \operatorname{MPWV}\left(\mathrm{O}_{2} \mathrm{H}^{-}+\mathrm{H}^{+}\right. \\
\operatorname{MPWV}\left(\mathrm{O}_{2} \mathrm{H}\right)^{-}+\mathrm{H}_{2} \mathrm{O} & \rightarrow \operatorname{MPWV}(\mathrm{OH})^{-}+2 \mathrm{OH}^{\cdot} \\
\operatorname{MPWV}(\mathrm{OH})^{-}+\mathrm{H}^{+} & \rightarrow \operatorname{MPWV}\left(\mathrm{H}_{2} \mathrm{O}\right) \\
\mathrm{HO}^{-}+\text {phenol } & \rightarrow \text { products }
\end{aligned}
$$

Even though the initial phenol concentration varies, phenol concentration diminishes with reaction time under the $\mathrm{Fe}_{5}(-$ $\left.\mathrm{PW}_{10} \mathrm{~V}_{2} \mathrm{O}_{40}\right)_{3}$ photo catalysis (Fig. 7a). This reaction time shows that the degradation rate apparently decreases with the increase in the initial phenol concentration. Therefore, a long time is required to fully degrade the phenol at high concentration. Phenol can be degraded completely under the condition of initial concentration of $25 \mathrm{mg} \mathrm{L}^{-1}$ and reaction time of $20 \mathrm{~min}$. This degradation displays obvious advantages in energy consumption and cost compared with the previously obtained results. ${ }^{42}$

When $\mathrm{H}_{2} \mathrm{O}_{2}$ was added, phenol was mainly degraded by the hydroxyl radicals produced by the $\mathrm{H}_{2} \mathrm{O}_{2}$ decomposition, so that $\mathrm{H}_{2} \mathrm{O}_{2}$ concentration is a key factor in controlling the rate of phenol degradation (Fig. 7b). The percentage of phenol degradation rises with the increasing concentration of $\mathrm{H}_{2} \mathrm{O}_{2}$ up to 0.2 $\mu \mathrm{mol} \mathrm{L} \mathrm{L}^{-1}$, but then declines when the concentration of $\mathrm{H}_{2} \mathrm{O}_{2}$ surpasses $0.2 \mu \mathrm{mol} \mathrm{L}{ }^{-1}$. This may be related to the disproportionation reaction and the "suppression" action of hydroxyl radicals at high $\mathrm{H}_{2} \mathrm{O}_{2}$ concentration. ${ }^{43}$ Kleiser had explained the suppression using the self-scavenging of $\mathrm{OH}$ radicals. At high

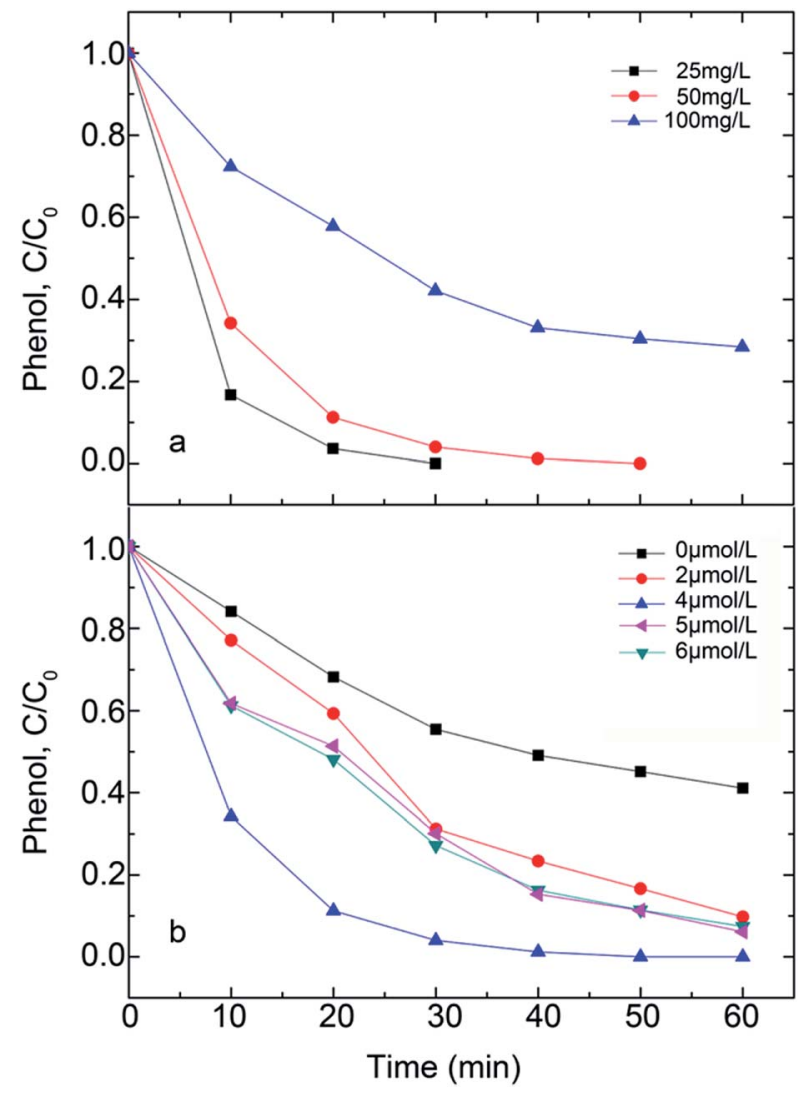

Fig. 7 Effect of (a) initial aqueous phenol concentration and (b) $\mathrm{H}_{2} \mathrm{O}_{2}$ concentration on phenol degradation. Reaction conditions: (a) $2 \mu \mathrm{mol}$ $\mathrm{L}^{-1} \mathrm{Fe}_{5}\left(\mathrm{PW}_{10} \mathrm{~V}_{2} \mathrm{O}_{40}\right)_{3}+4 \mu \mathrm{mol} \mathrm{L}{ }^{-1} \mathrm{H}_{2} \mathrm{O}_{2}+10 \mathrm{~W}$ UV lamp; (b) $50 \mathrm{mg} \mathrm{L}^{-1}$ phenol $+2 \mu \mathrm{mol} \mathrm{L}{ }^{-1} \mathrm{Fe}_{5}\left(\mathrm{PW}_{10} \mathrm{~V}_{2} \mathrm{O}_{40}\right)_{3}+10 \mathrm{~W}$ UV lamp.

$\mathrm{H}_{2} \mathrm{O}_{2}$ concentration, more hydroxyl radicals are formed. However, the high concentration of $\mathrm{H}_{2} \mathrm{O}_{2}$ means more $\mathrm{OH}$ radicals are scavenged by itself, as presented below. ${ }^{44}$

$$
\mathrm{H}_{2} \mathrm{O}_{2}+\mathrm{OH} \bullet \rightarrow \mathrm{HO}_{2}^{\cdot}+\mathrm{H}_{2} \mathrm{O}
$$

Herefore, in this study, it is found that the optimal concentration of $\mathrm{H}_{2} \mathrm{O}_{2}$ for phenol degradation is $0.2 \mu \mathrm{mol} \mathrm{L}^{-1}$.

\section{Conclusions}

Three heteropoly acid salts were successfully prepared and their effectiveness in the application to photocatalysis was studied. The results indicated that catalytic performance was all improved comparing with HPWV, and FePWV showed the best catalytic effect. The photocatalytic activities for degradation of phenol over FePWV reached $96 \%$ in $30 \mathrm{~min}$ in the case of $\mathrm{H}_{2} \mathrm{O}_{2}$ added simultaneously. In addition, $\mathrm{H}_{2} \mathrm{O}_{2}$ concentration is a key factor in controlling the rate of phenol degradation due to the balance of the forming and self-scavenging of $\mathrm{OH}$ radicals. However, more deep research such as the catalytic mechanisms, reusability test and application for other organic compounds still need to be further investigated. Recently, research in the field of novel catalysts has received intense interest, with 
a special focus on green, environmentally friendly catalysts. Therefore, heteropoly acid catalysts will probably become the novel catalyst used in the environmental applications of the future.

\section{Conflicts of interest}

There are no conflicts to declare.

\section{Acknowledgements}

This work was supported by the Project of Green Manufacturing system; the Open Subject of Jiangsu Key Laboratory of Anaerobic Biotechnology (JKLAB201605); the Young Doctorate Cooperation Fund Project of Advanced Materials Institute, Shandong Academy of Science (2018QNHZ04).

\section{References}

1 S. Wu, H. Li, X. Li, H. He and C. Yang, Chem. Eng. J., 2018, 353, 533-541.

2 A. Babuponnusami and K. Muthukumar, J. Environ. Chem. Eng., 2014, 2, 557-572.

3 L. F. Liotta, M. Gruttadauria, G. Di Carlo, G. Perrini and V. Librando, J. Hazard. Mater., 2009, 162, 588-606.

4 M. Pera-Titus, V. García-Molina, M. A. Baños, J. Giménez and S. Esplugas, Appl. Catal., B, 2004, 47, 219-256.

5 M. Bobu, S. Wilson, T. Greibrokk, E. Lundanes and I. Siminiceanu, Chemosphere, 2006, 63, 1718-1727.

6 M. N. Chong, B. Jin, C. W. Chow and C. Saint, Water Res., 2010, 44, 2997-3027.

7 S. Wang, Dyes Pigm., 2008, 76, 714-720.

8 V. Kavitha and K. Palanivelu, Int. J. Environ. Sci. Technol., 2016, 13, 927-936.

9 P. Maletzky and R. Bauer, Chemosphere, 1998, 37, 899-909.

10 M.-Y. Kuo, C.-F. Hsiao, Y.-H. Chiu, T.-H. Lai, M.-J. Fang, J.-Y. Wu, J.-W. Chen, C.-L. Wu, K.-H. Wei and H.-C. Lin, Appl. Catal., B, 2019, 242, 499-506.

11 J. Rodríguez-Chueca, M. P. Ormad, R. Mosteo and J. L. Ovelleiro, Chem. Eng. Sci., 2015, 138, 730-740.

12 B. Li, Y. Dong, M. Li and Z. Ding, J. Mater. Sci., 2014, 49, 7639-7647.

13 D. Liang, J. Li and G. Pang, J. Mater. Sci., 2016, 51, 54125420.

14 A. V. Russo, L. F. Toriggia and S. E. Jacobo, J. Mater. Sci., 2013, 49, 614-620.

15 M. Aleksić, H. Kušić, N. Koprivanac, D. Leszczynska and A. L. Božić, Desalination, 2010, 257, 22-29.

16 Y. Lin, S. Wu, C. Yang, M. Chen and X. Li, Appl. Catal., B, 2019, 245, 71-86.

17 B. Rodríguez-Cabo, I. Rodríguez-Palmeiro, R. Rodil, E. Rodil, A. Arce and A. Soto, J. Mater. Sci., 2015, 50, 3576-3585.

18 O. S. N. Sum, J. Feng, X. Hu and P. L. Yue, Chem. Eng. Sci., 2004, 59, 5269-5275.
19 Y.-H. Chiu and Y.-J. Hsu, Nano Energy, 2017, 31, 286-295.

20 S. Wu, H. He, X. Li, C. Yang, G. Zeng, B. Wu, S. He and L. Lu, Chem. Eng. J., 2018, 341, 126-136.

21 P. P. Yang, X. L. Wang, L. C. Li and D. Z. Liao, Dalton Trans., 2011, 40, 4155-4161.

22 L. Hong, H. F. Li, J. Sun, J. L. Zhu, G. H. Ai, L. Li, B. Zhang, F. L. Chi and X. W. Tong, J. Minim. Invasive Gynecol., 2012, 19, 684-688.

23 S. J. Freakley, R. J. Lewis, D. J. Morgan, J. K. Edwards and G. J. Hutchings, Catal. Today, 2015, 248, 10-17.

24 X. Han, W. Yan, K. Chen, C.-T. Hung, L.-L. Liu, P.-H. Wu, S.-J. Huang and S.-B. Liu, Appl. Catal., A, 2014, 485, 149-156.

25 J. A. Lopez, J. C. Lopez, D. E. Valerdi, G. G. Salgado, T. DiazBecerril, A. P. Pedraza and F. J. Gracia, Nanoscale Res. Lett., 2012, 7, 604.

26 D. W. Thompson, D. J. Seidel, W. J. Randel, C. Z. Zou, A. H. Butler, C. Mears, A. Osso, C. Long and R. Lin, Nature, 2012, 491, 692-697.

27 J. A. Asensio, E. M. Sanchez and P. Gomez-Romero, Chem. Soc. Rev., 2010, 39, 3210-3239.

28 J. Zhang, Y. Tang, Z. Luo, M. Jian and C. Hu, Chin. J. Inorg. Chem., 2014, 20, 935-940.

29 H. Zhang, R. Yan, L. Yang, Y. Diao, L. Wang and S. Zhang, Ind. Eng. Chem. Res., 2013, 52, 4484-4490.

30 X. Tong, N. Tian, W. Wu, W. Zhu, Q. Wu, F. Cao, W. Yan and A. B. Yaroslavtsev, J. Phys. Chem. C, 2013, 117, 3258-3263.

31 S. Venkateswarlu and M. Yoon, $R S C A d v ., 2015,5$, 6544465453.

32 S. Denis, E. Baudrin, M. Touboul and J. M. Tarascon, J. Electrochem. Soc., 1997, 144, 4099-4109.

33 I. V. Kozhevnikov, J. Mol. Catal. A: Chem., 2007, 262, 86-92. 34 A. Devadas, S. Baranton, T. W. Napporn and C. Coutanceau, J. Power Sources, 2011, 196, 4044-4053.

35 Q. Wu, X. Sang, F. Shao and W. Pang, Mater. Chem. Phys., 2005, 92, 16-20.

36 Y. Leng, J. Wang, D. Zhu, X. Ren, H. Ge and L. Shen, Angew. Chem., Int. Ed., 2009, 48, 168-171.

37 X. Tong, N. Tian, W. Zhu, Q. Wu, F. Cao and W. Yan, J. Alloys Compd., 2012, 544, 37-41.

38 N. Oturan, M. Zhou and M. A. Oturan, J. Phys. Chem. A, 2010, 114, 10605-10611.

39 X.-R. Xu, H.-B. Li, W.-H. Wang and J.-D. Gu, Chemosphere, 2004, 57, 595-600.

40 H. Bel Hadjltaief, P. Da Costa, P. Beaunier, M. E. Gálvez and M. Ben Zina, Appl. Clay Sci., 2014, 91-92, 46-54.

41 J. Chen and L. Zhu, Catal. Today, 2007, 126, 463-470.

42 M. Luo, S. Yuan, M. Tong, P. Liao, W. Xie and X. Xu, Water Res., 2014, 48, 190-199.

43 M. A. Oturan and J. Pinson, J. Phys. Chem., 1995, 99, 1394813954.

44 G. Kleiser and F. H. Frimmel, Sci. Total Environ., 2000, 256, 1-9. 